\title{
Implementasi Etika Islam Dalam Pemasaran Produk Bank Syariah
}

\author{
Abdul Hamid \\ Muhammad Kamal Zubair \\ Institut Agama Islam Negeri (IAIN) Parepare \\ abdulhamid@iainpare.ac.id
}

\begin{abstract}
Abstrak
Tenaga pemasaran merupakan sarana penghubung utama perusahaan dengan konsumen atau merupakan ujung tombak bisnis perusahaan. Bagi dunia perbankan yang merupakan badan usaha yang berorientasi profit, kegiatan pemasaran sudah merupakan suatu kebutuhan utama dan sudah merupakan suatu keharusan untuk dijalankan, oleh karena itu tenaga pemasar produk perbankan dituntut kreatif dan inovatif dalam melakukan kegiatan pemasaran. Kajian ini bertujuan untuk memahami perilaku tenaga pemasar bank syarih melalui penerapan etika bisnis Islam dalam memasarkan produk-produk bank syariah di kota Parepare. Hasil kajian menunjukkan bahwa para tenaga pemasar bank syariah di kota Parepare sepenuhnya telah mengimplementasikan nilai-nilai syariah yang merupakan bagian dari konsep etika bisnis Islam dalam kegiatan pemasarannya. Penerapan etika bisnis Islam pada tenaga pemasar bank syariah dinilai sangat tepat. Bank syariah yang mempunyai kualitas tenaga pemasaran berbasis etika Islam dapat membangun reputasi untuk keberhasilan perkembangan bank syariah di Parepare.
\end{abstract}

Kata Kunci : Pemasaran, Etika Islam, Bank Syariah

\section{Pendahuluan}

Permasalahan ekonomi pada dataran praktisnya adalah permasalahan yang dihadapi semua orang tanpa terkecuali. Hal ini dikarenakan permasalahan ekonomi berkaitan langsung dengan masalah pemenuhan kebutuhan manusia untuk melangsungkan hidupnya. ${ }^{1}$ Sistem Islam tentang kehidupan merupakan

\footnotetext{
1 Zubair, M. K. (2012). Aksioma Etika Dalam Ilmu Ekonomi Islam. EKBISI, 7(1), 88-100.
} 
sistem yang memiliki cakupan multi aspek. Seperti aspek peribadatan yang membawa ruh ke tingkat yang tinggi yang menghubungkan manusia dengan Allah. Aspek adab yang menuntun perilaku manusia ke derajat yang tinggi serta memperindah kehidupan. Selain itu juga mencakup syari'ah yang menjelaskan halal-haram, menegakkan keadilan, mengatur hubungan manusia dengan sesama manusia atas dasar ukhuwah, persamaan, keadilan dan saling melaksanakan hak dan kewajiban. Disamping itu juga terdapat sanksi bagi yang menyeleweng dari aturan Allah.

Masalah etika merupakan salah satu fondasi yang harus diciptakan dan dimiliki oleh setiap pelaku bisnis. Etika pada dasarnya adalah standar atau moral yang menyangkut benar-salah, baik-buruk. Dalam bahasa Kant, etika berusaha menggugah kesadaran manusia untuk bertindak secara otonom dan bukan secara heteronom. Etika bermaksud membantu manusia untuk bertindak secara bebas, tetapi dapat dipertanggungjawabkan. Bebas dan tanggung jawab adalah unsur pokok dari otonomi moral yang merupakan salah satu prinsip utama moralitas, termasuk etika bisnis. ${ }^{2}$

Etika dalam ajaran Islam menuntun seluruh aspek perilaku kehidupan manusia, hampir setiap individu berhadapan dengan berbagai permasalahan etis baik menjalankan bisnis ataupun menjalankan aktivitas sehari-hari. Bisnis yang sehat adalah bisnis yang berlandaskan etika, pelaku bisnis muslim hendaknya memiliki kerangka etika bisnis yang kuat sehingga mengantarkan aktivitas bisnis nyaman dan berkah. ${ }^{3}$

${ }^{2}$ Agus Arijanto, Etika Bisnis Bagi Pelaku Bisnis (Jakarta: Rajawali Pers, 2011), h. 22

${ }^{3}$ Muhammad, Etika Bisnis Islami (Yogyakarta: UPP-AMP YKPN, 2004), h. 95. 
Bisnis tidak dapat dipisahkan dari aktivitas pemasaran. Sebab pemasaran merupakan aktivitas perencanaan, pelaksanaan dan pengawasan atas program-program yang dirancang untuk menghasilkan transaksi pada target pasar, guna memenuhi kebutuhan perorangan atau kelompok berdasarkan asas saling menguntungkan, melalui pemanfaatan produk, harga, promosi, dan distribusi. Seiring dengan sejarah manusia dalam memenuhi kebutuhannya, ada pihak yang meminta dan ada yang menawarkan. Pemasaran menarik perhatian yang sangat besar baik dari perusahaan, lembaga maupun antar bangsa. Proses pemasaran menjadi bagian penting dalam menawarkan barang dagangan kepada calon pembeli. Apabila seorang pengusaha mempunyai manajemen pemasaran yang bagus, maka usahanya akan cepat berkembang.

Tenaga pemasaran merupakan sarana penghubung utama perusahaan dengan konsumen atau merupakan ujung tombak bisnis perusahaan. Kegiatan pemasaran untuk produk barang dan jasa, tentu saja berbeda dalam penggunaannya. Biasanya untuk produk barang sering kali diiklankan di media, sedangkan untuk jasa secara etis dan moral relatif sangat sedikit yang diiklankan kepada umum secara terbuka.

Dengan perkembangan teknologi informasi dan bisnis yang global maka teknik-teknik pemasaran pun bergeser dan berkembang cepat. Pemasaran bisa dilakukan dengan situs-situs, email, dan lain-lainnya. Semua dapat dilakukan secara cepat, efisien dan tanpa batasan wilayah dan waktu. Sehingga persaingan produk dan jasa saat ini semakin ketat. Oleh karena itu, tenaga pemasar produk perbankan dituntut kreatif dan inovatif dalam melakukan kegiatan pemasaran tersebut. ${ }^{4}$ Berbagai cara dilakukan untuk melayani dan memberikan kemudahan

\footnotetext{
${ }^{4}$ Agus Arijanto, Etika... , h. 53-54.
} 
bagi nasabah seperti pelayanan personal, sms banking, internet banking dan sebagainya. Selain sisi teknologi, perusahaan perbankan juga berlomba untuk memodifikasi strategi pemasaran. Bank harus dapat menciptakan strategi pemasaran yang mampu memberi sentuhan pelayanan personal dengan menciptakan komunikasi dua arah dengan membangun dan mengelola hubungan jangka panjang yang saling menguntungkan dengan para pelanggan.

\section{Konsep Etika Bisnis dalam Islam}

Pengertian etika atau seperti lazim disebut etik, berasal dari bahasa latin "ethica". Ethos dalam bahasa Yunani berarti norma-norma, nilai-nilai, kaidahkaidah ukuran-ukuran bagi tingkah laku yang baik..$^{5}$ Etika dapat didefinisikan sebagai seperangkat prinsip moral yang membedakan yang baik dan yang buruk. Etika adalah bidang ilmu yang bersifat normatif karena ia berperan menentukan apa yang harus dilakukan. ${ }^{6}$ Pada dasarnya, Etika berpengaruh terhadap para pelaku bisnis, terutama dalam hal kepribadian, tindakan dan perilakunya. Secara etimologi, Etika identik dengan moral, karena telah umum diketahui bahwa istilah moral berasal dari kata mos (dalam bentuk tunggal) dan mores (dalam bentuk jamak) dalam bahasa latin yang artinya kebiasaan atau cara hidup.7 Etika adalah ilmu yang berisi patokan-patokan mengenai apaapa yang benar atau salah, yang baik dan buruk, yang bermanfaat atau tidak bermanfaat oleh seorang individu ${ }^{8}$

${ }^{5}$ O.P. Simorangkir, Etika Bisnis, (Jakarta: Rineka Cipta, 2003) h. 82

${ }^{6}$ Dimyauddin Djuwaini, Pengantar Fiqh Muamalah (Yogyakarta: Pustaka Pelajar, 2008), h. $x x$

${ }^{7}$ A. Kadir, Hukum Bisnis Syariah dalam al-Quran,(Jakarta:Amzah, 2010) h. 47

${ }^{8}$ Muhammad, Etika ..., h. 15 
Dalam Islam, istilah yang paling dekat berhubungan dengan istilah etika dalam al-Quran adalah Khuluq. Al-Quran juga menggunakan sejumlah istilah lain untuk menggambarkan konsep tentang kebaikan :Khair (kebaikan), birr (kebenaran), qist (persamaan), 'adl (kesetaraan dan keadilan), haqq (kebenaran dan kebaikan), ma'ruf (mengetahui dan menyetujui) dan takwa (ketakwaan). Tindakan terpuji disebut dengan salihat dan tindakan yang tercela disebut sebagai sayyiat. ${ }^{9}$

Dalam khazanah pemikiran Islam, etika dipahami sebagai al-akhlak, al$a d a b$ atau falsafah al-adabiyah, yang mempunyai tujuan untuk mendidik moralitas manusia. Ahmad Amin memberikan batasan bahwa etika atau akhlak adalah ilmu yang menjelaskan arti baik dan buruk, menerangkan apa yang seharusnya dilakukan oleh manusia kepada lainnya, menyatakan tujuan yang harus dituju oleh manusia di dalam perbuatan mereka dan menunjukkan jalan untuk melakukan apa yang harus diperbuat, ${ }^{10}$

Ketika etika dipahami sebagai seperangkat prinsip moral yang membedakan apa yang benar dari apa yang salah, maka etika diperlukan dalam bisnis. Sebagaimana diketahui, bahwa bisnis adalah suatu serangkaian peristiwa yang melibatkan pelaku bisnis. Para pelaku bisnis memiliki kecenderungan untuk melakukan tabrakan kepentingan, saling menghalalkan cara, dalam rangka memperoleh keuntungan sebanyak mungkin, bahkan saling membunuh, sehingga pelaku bisnis yang kuat kian mendominasi, sementara yang lemah terperosok di sudut-sudut ruang bisnis. Bisnis yang sehat adalah bisnis yang berlandaskan pada etika. Oleh karena itu, pelaku bisnis muslim hendaknya

\footnotetext{
${ }_{9}^{9}$ Veithzal Rivai, dkk., Islamic Business and Economic Ethics, (Jakarta;Bumi Aksara, 2012), h.3

${ }^{10}$ Muhammad, Etika..., h. 64-65
} 
memiliki kerangka etika bisnis yang kuat, sehingga dapat mengantarkan aktivitas bisnis yang nyaman dan berkah. ${ }^{11}$

\section{Etika Islam Tentang Pemasaran}

Menurut Kamus Besar Bahasa Indonesia (KBBI) Pengertian Pemasaran adalah proses, cara, atau perbuatan memasarkan suatu barang dagangan. ${ }^{12}$ Pengertian pemasaran menurut beberapa ahli adalah sebagai berikut : Menurut William J.Staton, Pemasaran adalah suatu sistem total dari kegiatan bisnis yang dirancang untung merencanakan, menentukan, harga promosi dan mendistribusikan barangbarang yang dapat memuaskan keinginan dan mencapai pasar sasaran serta tujuan perusahaan.

Definisi pemasaran menurut Khasmir adalah suatu usaha untuk memenuhi kebutuhan dan keinginan para nasabahnya terhadap produk dan jasa. ${ }^{13}$ Pemasaran pada intinya adalah suatu proses sosial yang merancang dan menawarkan sesuatu yang menjadi kebutuhan dan keinginan dari nasabah dalam rangka memberikan kepuasan yang optimal kepada nasabah. ${ }^{14}$ Dari pengertian tersebut, dapat diambil kesimpulan pemasaran adalah sebuah kegiatan yang dilakukan dalam rangka merencanakan, mengorganisasikan, mempromosikan, dan untuk mewujudkan tujuan perusahaan. Menurut pengertian di atas dapat disimpulkan bahwa pengertian etika pemasaran adalah sebuah kegiatan yang dilakukan secara terus menerus dalam merencanakan,

\footnotetext{
11Muhammad, Etika..., h. 95

12 Pagut Lubis, Kamus Besar Bahasa Indonesia Pusat Bahasa Indonesia, (Jakarta: PT Gramedia Pustaka Utama,2012), h. 1027.

${ }^{13}$ Khasmir, Pemasaran Bank, Jakarta: Kencana, 2010, hlm 53

h. 6

${ }^{14}$ Nur Rianto Al Arif, Dasar- Dasar Pemasaran Bank Syariah, (Bandung : Alfabeta, 2010),
} 
mengorganisasikan, mempromosikan, dan mendistribusikan barang dan jasa yang dilakukan sebuah perusahaan untuk mendapatkan keuntungan dengan menggunakan prinsip keadilan dan kejujuran.

Menurut Kotler definisi pemasaran berarti bekerja dengan pasar sasaran untuk mewujudkan pertukaran yang potensial dengan maksud memuaskan kebutuhan dan keinginan manusia. Sehingga dapat dikatakan bahwa keberhasilan pemasaran merupakan kunci kesuksesan dari sutu perusahaan. ${ }^{15}$

Etika pemasaran Islam didasarkan pada maksimalisasi nilai yang memerlukan empati terhadap orang lain dan menghargai ciptaan-ciptaan Allah, yang menyiratkan menahan diri dari perilaku merugikan orang lain dan mencegah merebaknya praktik-praktik pemasaran yang tidak etis. Kepatuhan terhadap kerangka etika Islam yang didasarkan pada kejujuran dan keadilan menjamin martabat dan kebebasan baik manusian (konsumen maupun produsen), pikiran, hati nurani mereka dari semua jenis perbudakan

Pemasaran merupakan salah satu kegiatan pokok yang dilakukan oleh para pengusaha untuk mempertahankan kelangsungan hidup usahanya, berkembang dan untuk mendapatkan laba. ${ }^{16}$ Penafsiran yang sempit tentang pemasaran ini terlihat pula dari definisi American Marketing Association 1960, yang menyatakan pemaaran adalah hasil prestasi kerja kegiatan usaha yang berkaitan dengan mengalirnya barang dan jasa dari produsen sampai ke konsumen. Di samping penafsiran ini terdapat pula pandangan yang lebih luas,

15 Danang Sunyoto, Prilaku Konsumen dan Pemasaran, (Yogyakarta, Center of Academic Publishing Service, 2015), h.191

${ }^{16}$ Abdul Muiz, Strategi Pemasaran Dalam Perspektif Etika Bisnis Islam, http://abdulmuiz18.blogspot.co.id/2012/03/800x600-normal-0-false-false-false-in-x_18.html (diakses pada 13 Mei 2017) 
yang menyatakan pemasaran merupakan proses kegiatan yang mulai jauh sebelum barang-barang/ bahan-bahan masuk dalam proses produksi. Dalam hal ini banyak keputusan pemasaran yang harus dibuat jauh sebelum produk itu dihasilkan, seperti keputusan mengenai produk yang dibuat, pasarnya, harga dan promosinya. ${ }^{17}$

Inti dari pemasaran (marketing) adalah mengidentifikasi dan memenuhi kebutuhan manusia dan sosial. Salah satu definisi yang baik dan singkat dari pemasaran adalah "memenuhi kebutuhan dengan cara yang menguntungkan". ${ }^{18}$ Setiap perusahaan mempunyai tujuan untuk dapat tetap hidup dan berkembang; tujuan tersebut hanya dapat dicapai melalui usaha mempertahankan dan meningkatkan tingkat keuntungan/ laba perusahaan. Usaha ini hanya dapat dilakukan apabila perusahaan dapat mempertahankan dan meningkatkan penjualannya, melalui usaha mencari dan membina langganan, serta usaha menguasai pasar. ${ }^{19}$

Etika perilaku penjualan dapat memainkan peran penting dalam pembentukan dan pemeliharaan hubungan jangka panjang dengan para nasabah, $^{20}$ dan dapat menimbulkan masalah laporan pertanggungjawaban organisasi tenaga penjualan baik sengaja maupun tidak sengaja. ${ }^{21}$

${ }^{17}$ Sofjan Assauri, Manajemen Pemasaran (Jakarta: PT Raja Grafindo Persada, 2014), h. 3

18Philip Kotler, Kevin Lane Keller, Manajemen Pemasaran (Jakarta: Penerbit Erlangga, 2008), h. 5.

${ }^{19}$ Sofjan Assauri, Manajemen ..., h. 167.

${ }^{20}$ Wray, B., Palmer, A. and Bejou, D., "Using Neural Network Analysis to Evaluate BuyerSeller Relationships." European Journal of Marketing, 1994, Vol. 28, No. 10, h.. 32-48.

${ }^{21}$ Boedecker, K.A., Morgan, F.W. and Stoltman, J.J., "Legal Dimensions of Salesperson's Statements: A Review and Managerial Suggestions", Journal of Marketing, 1991, Vol. 55, h..70-80 
Muhammad Syakir Sula dan Hermawan Kartajaya dalam buku Marketing Syariah, mendefinisikan pemasaran sebagai sebuah disiplin bisnis strategis yang mengarahkan pada proses penciptaan, penawaran, dan perubahan nilai dari suatu inisiator kepada para pemegang sahamnya, yang dalam keseluruhan prosesnya sesuai dengan akad dan prinsip-prinsip muamalat bisnis dalam Islam. ${ }^{22}$

Kegiatan Pemasaran Islami merupakan bentuk muamalah yang didasarkan pada firman Allah dan dicontohkan oleh Rasulullah SAW, maka dalam kegiatannya tentu tidak boleh ada kegiatan yang bertentangan dengan akad dan prinsip-prinsip muamalah. Pemasaran Islam pada dasarnya memiliki 4 (empat) prinsip dasar yang dapat menjadi panduan bagi para tenaga pemasar.

\section{Penerapan Nilai-Nilai Etika Islam Dalam Pemasaran Produk Bank Syariah}

Bisnis perbankan saat ini semakin dinamis sehingga memacu para pengelola perbankan untuk dapat berpikir secara kreatif, inovatif dengan memberikan keunggulan produk dan jasa dibandingkan dengan para pesaingnya. Berbisnis dengan beretika Islam, seharusnya tidak hanya menjadi wacana dan slogan yang dipajang di sudut-sudut ruang kantor bank syari'ah, tetapi sebaiknya bisa diterapkan dalam kehidupan nyata, khususnya tenaga pemasar bank syariah.

Etika bisnis Islam sebagai suatu acuan yang amat penting perlu menjadi pedoman utama bagi para tenaga pemasaran bank syari'ah. Tanpa kekuatan etika Islam, para tenaga pemasaran bank syariah akan terjebak ke dalam suatu

22 Syakir Sula dan Kertajaya Hermawan, Syariah Marketing, (Bandung : PT Mizan Pustaka, 2006), h 110. 
bisnis islami yang tidak beretika. Akibatnya tidak hanya institusi perbankan syariah saja yang dianggap tidak punya integritas di mata masyarakat, tetapi bisa jadi Islam sebagai agama yang terbaik juga dianggap tidak punya sistem yang benar. Pembahasan berikut ini akan melihat sejauhmana penerapan etika bisnis Islam oleh tenaga pemasar bank syariah, khususnya yang ada di Parepare.

Hasil penelitian di beberapa bank syariah yang telah beroperasi di Parepare menunjukkan bahwa bank syariah di Parepare telah menggunakan teknologi yang canggih dan memiliki sumber daya insan yang berkualitas, namun demikian bank syariah juga harus mulai mengedepankan nilai-nilai etika bisnis Islam. Tenaga pemasaran yang beretika Islam sangat cocok untuk memasarkan produk dan jasa perusahaan untuk meraih keunggulan bersaing. Pada era di mana etika bisnis menjadi kurang diperhatikan dan kejujuran menjadi sesuatu yang langka maka langkah ini akan menjadi sumber daya saing yang utama.

Nilai-nilai etika Islam telah diterapkan dan dijalankan dengan baik sesuai dengan ajaran Islam demi mempertahankan nasabah bank syariah. Hal ini sesuai dengan keterangan salah satu responden sebagai berikut:

"tenaga pemasar bank syariah bersikap terbuka, jujur dan menjaga amanah dalam memberikan informasi terkait dengan produk dan jasa bank syariah yang ditawarkan"23

Untuk menjaga hak-hak pelaku bisnis dan menghindari transaksi yang menyebabkan penyimpangan dalam menghadapi nasabah, tenaga pemasar bank syariah membutuhkan kaidah-kaidah dan etika bisnis yang dapat dijadikan acuan dalam kegiatan pemasaran yang dijalankan. Nilai-nilai etika senantiasa dijalankan dalam rangka untuk pemahaman etika bisnis Islam

23Wawancara dengan Bapak Abdil, nasabah BTN Syariah Parepare, tgl. 15 Oktober 2017 
dan diaplikasikan oleh mereka dalam melakukan aktifitas pemasaran. Perilaku tersebut ditunjukkan dalam sikap antara lain: kejujuran, kerja sama, komitmen, disiplin, dan tanggung jawab.

Menurut Bapak Sotoyo selaku Kepala Cabang BNI Syariah Parepare:

“Dunia pemasaran perlu menunjukkan nilai-nilai spiritual dalam pemasaran. Etika pemasaran Islam diterapkan dalam rangka memperoleh manfaat serta keuntungan bagi perusahaan." 24

Sedangkan menurut Bapak Sulthon Agung, pimpinan Bank BTN Syariah:

"Pemasaran yang beretika dan jujur akan memaksimalkan pencapaian kepuasan pemangku kepentingan (stakeholder) secara seimbang. Nilai-nilai yang ditebarkan itu diyakini tidak hanya mendongkrak profit tetapi juga menjamin kelanggengan dan penguatan karakter brand, sekaligus membentuk diferensiasi yang tidak tertandingi." 25

Bank BNI syariah dan BTN Syariah Parepare memiliki beberapa pedoman etika bisnis yang dijadikan prinsip dasar jalannya kegiatan usaha dan operasional perbankan syariah. Etika bisnis tersebut terbagi menjadi tiga yaitu, etika manajemen, etika pemasaran, dan etika lingkungan. Pembagian etika bisnis menjadi tiga aspek didasari pada aktivitas perekonomian perusahaan secara garis besar terbagi menjadi tiga bagian yaitu: aktivitas manajemen, hubungan antara pemimpin dengan karyawan maupun karyawan dengan sesama karyawan dalam menjalankan kegiatan usaha dan operasional perusahaan; aktivitas pemasaran, termasuk di dalamnya produk yang

\footnotetext{
${ }^{24}$ Wawancara dengan Bapak Sutoyo, Pemimpin Cabang Bank BNI Syariah Mikro Syariah Parepare, tgl. 2 Oktober 2017

${ }^{25}$ Wawancara dengan Bapak Sulthon Agung, Kepala Cabang BTN Syariah Parepare, tgl. 27 Oktober 2017
} 
dihasilkan sampai pada strategi pemasaran perusahaan; aktivitas lingkungan, hubungan antara perusahaan dengan lingkungan sosial dan lingkungan hidup yang berada di sekitar perusahaan.

Pedoman etika pemasaran yang diterapkan bank syariah berfungsi sebagai pengingat bahwa dalam kegiatan opersional bank syariah bukan hanya terfokus pada pencapaian keuntungan secara maksimal namun juga keberkahan yang didapat. Demikian yang dikatakan oleh beberapa tanaga pemasar bank Syariah yang ada di Parepare, menurut mereka tidak ada kendala dalam menerapkan etika bisnis. Tanaga pemasar mempraktekkan etika bisnis yang dilakukan oleh Rasulullah, diantaranya jujur, amanah, menepati janji, tidak menggunakan sumpah dan melebih-lebihkan fakta produk dan melayani dengan sikap ramah dengan nasabah.

Pemasaran dengan penerapan etika bisnis Islam merupakan strategi bisnis yang mengarahkan proses penciptaan, penawaran, dan perubahan value (nilai) dari tenaga pemasar sebagai inisiator kepada stake holders yang dalam keseluruhan prosesnya sesuai prinsip-prinsip etika pemasaran dalam Islam.

Untuk memahami lebih jauh bagaimana penerapan etika bisnis Islam dalam pemasaran, terlebih dahulu perlu dipaparkan bahwa etika bisnis merupakan bagian dari etika profesi. Kata etika sudah menjadi bagian tak terpisahkan dalam dunia bisnis. Bukan hanya sebagai alat untuk menilai pantas atau tidak pantas; benar atau salah; buruk atau baik; etika bisnis juga menjadi perekat dalam setiap transaksi bisnis, menjadi aturan yang menjamin keterlaksanaan transaksi yang adil dan saling menguntung pihakpihak yang terlibat. Dalam arti lain etika bisnis berarti seperangkat prinsip dan norma di mana para pelaku bisnis dalam bertransaksi, berperilaku, dan berelasi guna mencapai tujuan-tujuan bisnisnya senantiasa berpegang teguh 
pada nilai-nilai etika bisnis. Selain itu, etika bisnis juga dapat berarti pemikiran atau refleksi tentang moralitas dalam ekonomi dan bisnis, yaitu refleksi tentang perbuatan baik, buruk, terpuji, tercela, benar, salah, wajar, tidak wajar, pantas, tidak pantas dari perilaku seseorang dalam berbisnis atau bekerja. ${ }^{26}$

Dalam menjalankan sebuah etika bisnis ada beberapa prinsip yang harus dimilki seorang profesional, di antaranya :

1. Prinsip tangung jawab.

Prinsip tanggung jawab dalam hal ini meliputi tanggungjawab seorang profesional terhadap profesi yang dijalaninya dan tanggungjawab terhadap masyarakat yang merasakan dampak dari profesi yang dilakukannya.

2. Prinsip keadilan.

Prinsip keadilan menuntut seorang profesional untuk bersikap adil dalam menjalankan profesinya agar masyarakat dapat merasakan manfaat dari profesi yang dijalankan dan tidak merasa dirugikan serta dapat memperoleh hak- haknya.

3. Prinsip otonomi

Prinsip otonomi merupakan hak yang dimiliki kaum profesional untuk menjalankan profesinya secara bebas. Otonomi di sini membatasi kaum profesional untuk selalu menjalankan profesinya dengan tanggungjawab dan bersikap profesional.

4. Prinsip integritas moral

Prinsip integritas moral ini menuntut seorang profesional untuk menjaga

${ }^{26}$ Achmad Charris Zubair, Kuliah Etika, (Jakarta:Rajawali Press, 1995), hlm 13-15 
nama baiknya, menjaga keluhuran profesinya dan menjaga kepentingan masyarakat.

Data mengenai penerapan etika bisnis Islam pada tanaga pemasar bank syariah menunjukkan bahwa secara umum etika pemasaran dalam Islam merupakan sejumlah perilaku etis bisnis yang dibungkus dengan nilainilai syari'ah. Jadi perilaku pemasaran yang beretika Islam adalah perilaku yang mengikuti perintah Allah dan menjauhi larangan-Nya.

Etika dapat didefinisikan sebagai satu usaha sistematis, dengan menggunakan akal untuk memaknai individu atau sosial kita, pengalaman moral, di mana dengan cara itu dapat menentukan peran yang akan mengatur tindakan manusia dan nilai yang bermanfaat dalam kehidupan. Dengan realitas semacam ini, maka menjadi semakin jelas bahwa di dalam Islam tidak ada pemisah antara etika pada satu sisi dan aktifitas pemasaran pada sisi yang lain. Aktivitas pemasaran berada dalam satu kesatuan bangunan dengan etika. Pada hakekatnya etika merupakan bagian integral dalam aktivitas pemasaran yang dijalankan secara professional.

Dalam jangka panjang suatu aktivitas pemasaran akan tetap berkesinambungan dan secara terus menerus benar-benar menghasilkan keuntungan jika dijalankan atas dasar-dasar kepercayaan dan kejujuran. Demikian pula suatu aktivitas pemasaran dalam bank syariah akan berlangsung dengan baik bila dilakukan dengan memberi perhatian yang lebih kepada semua nasabah. Inilah sebagian dari tujuan etika bisnis Islam, yaitu agar semua orang yang terlibat dalam aktivitas pemasaran mempunyai kesadaran tentang adanya dimensi etis dalam pemasaran itu sendiri, dan akan belajar bagaimana mengadakan pertimbangan yang baik secara etis maupun ekonomis. 
Bank syariah merupakan suatu sistem perbankan yang pelaksanaannya berdasarkan syariah Islam. Pembentukan sistem ini berdasarkan adanya larangan dalam agama Islam untuk meminjamkan atau memungut pinjaman dengan mengenakan bunga pinjaman (riba), serta larangan untuk berinvestasi pada usaha-usaha berkategori terlarang atau haram.

Dalam aktifitas sebagai tenaga pemasar, nilai-nilai etika senantiasa dikerjakan oleh seluruh tenaga pemasar. Nilai-nilai tersebut meliputi keadilan, kejujuran, kerja sama, komitmen, disiplin, dan tanggung jawab serta keikhlasan dalam bekerja. Ini semua dijalankan dalam rangka untuk pemahaman etika bisnis Islam dan dijadikan sebagai strategi untuk mengembangkan bank syariah. Keputusan masyarakat untuk menjadi nasabah pada sebuah bank syariah dapat dipengaruhi oleh tenaga pemasaran yang beretika Islam. Oleh karena itu bank syariah memprioritaskan kepuasan nasabah yang diwujudkan dalam jaminan kualitas produk serta pelayanannya.

Bagi tanaga pemasar bank-bank syariah di Parepare, pemasaran yang berhasil sudah tentu memiliki konsep yang baik, tidak ada unsur penipuan maupun ketidakjujuran, biasanya pemasaran seperti ini menggunakan konsep religius atau memasukkan unsur-unsur keagamaan, sehingga ada kehati-hatian dalam memasarkannya. Konsep pemasaran syariah ini sendiri berkembang seiring berkembangnya ekonomi syariah. Beberapa bank khususnya yang berbasis syariah telah menerapkan konsep ini dan telah mendapatkan hasil yang positif. Pemasaran syariah ini akan terus berkembang dan dipercaya masyarakat karena nilai-nilainya yang sesuai dengan apa yang dibutuhkan masyarakat, yaitu kejujuran.

Nilai inti dari pemasaran syariah adalah integritas dan transparansi, sehingga pemasar tidak boleh bohong dan orang membeli karena butuh dan 
sesuai dengan keinginan dan kebutuhan, bukan karena diskonnya. Pemasaran syariah adalah sebuah disiplin bisnis strategis yang mengarahkan proses penciptaan, penawaran dan perubahan value dari suatu inisiator kepada stakeholder, yang dalam keseluruhan prosesnya sesuai dengan akad dan prinsip-prinsip etika bisnis dalam Islam. Ini artinya bahwa dalam pemasaran syariah, seluruh proses, baik proses penciptaan, proses penawaran, maupun proses perubahan nilai (value), tidak boleh ada hal-hal yang bertentangan dengan akad dan prinsip-prinsip etika bisnis Islam. Sepanjang hal tersebut dapat dijamin, dan penyimpangan prinsip-prinsip etika bisnis Islam tidak terjadi dalam suatu transaksi apapun dalam pemasaran dapat dibolehkan.

Beberapa temuan dalam penelitian ini terkait dengan tenaga pemasar bank syariah di Parepare, antara lain:

1. Tenaga pemasar bank syariah melayani nasabah dengan penuh keikhlasan. Bagi mereka, nasabah adalah seorang raja yang harus dihormati. Berdasarkan konsep syariah, seorang tenaga pemasar harus melayani nasabah dengan sepenuh hati. Dalam hal ini tenaga pemasar bank syariah di Parepare biasanya mengunjungi tempat para calon/nasabah secara langsung dengan berlaku menjadi Customer Service yang menjelaskan produk dan layanan secara baik dan jelas.

2. Tenaga pemasar bank syariah melayani nasabah dengan jujur dan transparan. Ketika memasarkan sebuah produk, tenaga pemasar bank syariah akan mengungkapkan kelemahan dan keuntungan dari produk serta memberikan penjelasan mengenai manfaat produk. Melayani nasabah dengan layanan yang baik dan menawarkan beragam produk yang sesuai harapan nasabah dengan prinsip syariah dan nasabah akan membeli suatu produk karena butuh dan sesuai dengan keinginan dan kebutuhan. 
3. Tenaga pemasar bank syariah akan memenuhi janji kepada nasabah.

Nilai sebuah produk disesuaikan dengan apa yang dijanjikan. Tenaga pemasar bank syariah memberikan jaminan bagi produk yang akan dijual.

4. Tenaga pemasar bank syariah sangat memegang teguh etika Islam.

Tenaga pemasar syariah melakukan bisnis secara profesional dengan nilainilai yang menjadi landasan, antara lain yaitu (1) Memiliki kepribadian spritual (taqwa); (2) Berperilaku baik dan simpatik (sidiq) dalam menciptakan nilai pelanggan unggul; (3) Berlaku adil dalam memasarkan produk (al adil); (4) Melayani pelanggan dengan senyum dan rendah hati (khidmat); (5) Menepati janji dan tidak curang (tahfif), (6) Jujur dan terpercaya (al-amanah); (7) Tidak suka berburuk sangka (su'uzhzhann); (8) Tidak menjelek-jelekkan (ghibah) pesaing bisnis lain karena ghibah artinya keinginan untuk menghancurkan harga diri, kemuliaan dan kehormatan orang lain; (9) Tidak melakukan sogok (risywah), karena termasuk dalam kategorimemakan harta orang lain dengan cara batil.

Selain itu ada lima hal sifat yang harus dimiliki oleh seorang tenaga pemasar bank syariah parepare, yang selalu ditekankan dalam briefing setiap pagi, yaitu:

(1) Shiddiq (benar dan jujur)

Sifat shiddiq haruslah menjiwai seluruh prilaku seorang tenaga pemasar bank syariah dalam melakukan pemasaran, baik dalam berhubungan dengan nasabahn, dalam bertransaksi dengan nasabah, maupun dalam membuat perjanjian dengan nasabah;

(2) Amanah (terpercaya, kredibel): 
dapat dipercaya, bertanggung jawab, dan kredibel, juga bermakna keinginan untuk memenuhi sesuatu sesuai dengan ketentuan. Diantara nilai yang terkait dengan kejujuran dan melengkapinya adalah amanah;

(3) Fathanah (cerdas)

Diartikan sebagai intelektual, kecerdikan atau kebijaksanaan. Pemimpin yang fathanah adalah pemimpin yang memahami, mengerti dan menghayati secara mendalam segala hal yang menjadi tugas dan kewajibannya;

(4) Tabligh (komunikatif)

Orang yang memiliki sifat ini akan menyampaikannya dengan benar dan dengan tutur kata yang tepat. Berbicara dengan orang lain dengan sesuatu yang mudah dipahaminya, berdiskusi dan melakukan presentasi bisnis dengan bahasa yang mudah dipahami sehingga orang tersebut mudah memahami pesan bisnis yang ingin kita sampaikan;

(5) Istiqamah

Seorang pemasar syariah dalam praktik pemasarannya selalu istiqamah dalam penerapan aturan syariah. Kelima sifat ini merupakan sifat-sifat Nabi Muhammad SAW yangsudah sangat dikenal tapi masih jarang diimplementasikan khususnya dalam dunia bisnis

Dalam melakukan pemasaran kepada nasabah dan calon nasabah. Mereka sangat menghindari kebohongan, berlebihan dalam promosi, menjaga kejujuran dan janji. Nasabah dalam pemasaran syariah diletakkan sebagai mitra yang sejajar. Oleh karena itu, tidak boleh melakukan aktivitas pemasaran yang 
merugikan nasabah. Selalu berupaya menciptakan nilai produk yang positif dan umpan balik dari nasabah. Melayani nasabah dengan layanan yang baik dan menawarkan beragam produk yang sesuai harapan nasabah dengan prinsip syariah. Dengan tingkat persaingan antar bank yang semakin ketat serta didukung keunggulan-keunggulan yang di miliki antar bank, mendorong bank Syariah di Parepare lebih meningkatkan pelayanan-pelayanan yang ada agar sesuai dengan syariah.

.Jadi dengan pemasaran yang berbasis etika Islam, maka seluruh proses tidak boleh ada yang bertentangan dengan prinsip-prinsip Islam. Dan selama proses dan rangkaian aktivitas pemasaran dapat dijamin atau tidak ada penyimpangan terhadap prinsip-prinsip etika Islam. Proses pemasaran yang berbasis etika Islam dilaksanakan oleh orang yang memasarkan produk dengan menggunakan cara syariah yang biasa disebut juga dengan pemasar syariah. Tenaga pemasar syariah adalah para pemasar profesional dengan penampilan yang bersih, rapi dan bersahaja, apapun model atau gaya pakaian yang dikenakannya. pemasaran yang berbasis etika Islam adalah konsep pemasaran yang fleksibel, sebagaimana keluasan dan keluwesan syariah Islam yang melandasinya.

Pemasaran yang berbasis etika Islam bukanlah konsep yang eksklusif, fanatik, anti modernitas dan kaku. Konsep ini sebenarnya tidak berbeda jauh dari konsep pemasaran yang kita kenal. Perbedaannya adalah pemasaran yang berbasis etika Islam mengajarkan pemasar untuk jujur pada konsumen atau orang lain. Nilai-nilai syariah mencegah tenaga pemasar melakukan hal-hal yang bertentangan dengan nilai-nilai syariah, khususnya nilai-nilai etika bisnis Islam. Pemasaran yang berbasis etika Islam dibimbing oleh nilai-nilai akidah yaitu kejujuran, amanah (kredibel, tanggung jawab), fathanah (cerdas dan 
bijaksana), tabliqh (komunikatif). Pemasaran yang berbasis etika Islam mendorong pemasar agar menjadikan kegiatan pemasaran itu sebagai ibadah.

\section{Kesimpulan}

Bank syariah Parepare sepenuhnya mengimplementasikan konsep etika bisnis Islam kepada para tenaga pemasaran. Dalam praktiknya, kegiatan pemasaran yang dilakukan oleh Bank syariah Parepare didasarkan pada kaidah yang ada dan tidak bertentangan dengan prinsip syariah. Dalam artian konsep etika bisnis Islam yang diusung adalah konsep yang sederhana namun tetap didasarkan pada nilai keadilan dan kejujuran. Dengan kedua aspek tersebut, Bank syariah Parepare mampu mengimplementasikan nilai-nilai syariah dalam kegiatan pemasarannya. Penerapan etika bisnis Islam pada tenaga pemasar bank syariah dinilai sangat tepat. Bank syariah yang mempunyai kualitas tenaga pemasaran berbasis etika Islam dapat membangun reputasi bank syariah.

\section{Daftar Pustaka}

Abul Hassan, Abdel Kader Chachi, and Salma Adbul Latiff, "Islamic Marketing Ethics and Its Impact on Customer Satisfaction in The Islamic Banking Industry", J.KAU, Islamic Econ., 2008, Vol. 21, No.1, p. 23-40.

Abdul Muiz, Strategi Pemasaran Dalam Perspektif Etika Bisnis Islam, http://abdulmuiz18.blogspot.co.id/2012/03/800x600-normal-0false-false-false-in-x 18.html

Ahmad, M., Business Ethics In Islam, IIIT, Islamabad, 1995.

Arifin, Johan, Etika Bisnis Islami (Semarang: Walisongo Press, 2009) 
Ahmad, Mustaq. Etika Bisnis dalam Islam. 2001.Jakarta: Pustaka Al Kautsar.

Arifin, Zaenal, Dasar-dasar Manajemen Bank Syariah, Jakarta: Pustaka Alvabet, Cet.4, 2006.

Arijanto, Agus. 2011. Etika Bisnis bagi Pelaku Bisnis. Jakarta: Rajawali Pers.

Assauri, Sofjan, Manajemen Pemasaran (Jakarta: PT Raja Grafindo Persada, 2014)

Al Arif, Nur Rianto. Dasar- Dasar Pemasaran Bank Syariah.2010. Bandung : Alfabeta.

Anoraga, Pandji. Manajemen Bisnis. 1997. Jakarta :Rineka Cipta dan Sekolah Tinggi Ilmu Ekonomi (STIE) Bank BPD Jateng

Bagyo Mujiharjo, Analisis Faktor-faktor yang Mempengaruhi Kepuasan Pelanggan dan Pengaruhnya terhadap Loyalitas Pelanggan (Studi padaRumah Sakit BRI Demak), Jurnal Sains Pemasaran Indonesia, VolumeV,No 2 Tahun 2006.

Boedecker, K.A., Morgan, F.W. and Stoltman, J.J., "Legal Dimensions of Salesperson's Statements: A Review and Managerial Suggestions", Journal of Marketing, 1991, Vol. 55

Badroen, Faisal, Etika Bisnis dalam Islam (Jakarta: Kencana, 2006)

Dunfee, T.W. and Gunther, R., "Ethical Issues in Financial Services”, Business and Society Revieuy, 1999, Vol. 10

Djakfar, Muhammad. Hukum Bisnis: Membangun Wacana Integrasi Perundangan Nasional dengan Syariah. 2009. Yogyakarta : PT LKIS Printing Cemerlang

Djakfar, Muhammad.. Etika Bisnis Islami: Tataran Teoritis dan Praktis. 2008. Malang : UIN Malang Press

Djuwaini, Dimyauddin, Pengantar Fiqh Muamalah (Yogyakarta: Pustaka Pelajar, 2008

Gazalba, Sidi, Sistematika Filsafat, Buku Keempat; Pengantar Kepada Teori Nilai (Jakarta: Bulan Bintang, 2002) 
Kartajaya, Hermawan, Muhammad Syakir Sula. 2005.Syariah Marketing. Tangerang: Kholam Publishing.

Khasmir, Pemasaran Bank, (Jakarta: Kencana, 2010)

Kotler, Philip, Kevin Lane Keller. 2008. Manajemen Pemasaran. Jakarta:Penerbit Erlangga.

Laurence, B., 'Do Corporations Institutionalize Dishonesty', in Ethics: The Enemy in the Work Place, International Thomson Publishing Company, Ohio, 1995.

Lubis, Suhrawadi K., Etika Profesi Hukum (Jakarta : Sinar Grafika, 2002)

Lubis, Pagut, Kamus Besar Bahasa Indonesia Pusat Bahasa Indonesia, (Jakarta: PT Gramedia Pustaka Utama,2012)

Muhammad. 2008.Metodologi Penelitian Ekonomi Islam pendekatan Kuantitatif Jakarta: Rajawali Pers.

Morgan, R. M. Dan S.D. Hunt, "The Commitment Kepercayaan Theory of Relantionship Marketing." Journal of Marketing , Vol. 58, No.3

Mowen, C. John dan Michael Minor.. Perilaku Konsumen. (Jakarta: Erlangga 2002)

Oliver, R. L. Satisfaction : A Behavioral Perspective On The Consumer (New York: McGraw Hill Companies, Inc.,1997)

Rivai, Veithzal, Andria Permata Veithzal, Ferry N. Idroes, Bank and Financial Institution Management Conventional and Sharia System, Jakarta: PT RajaGrafindo Persada, 2007.

Rivai, Veithzal, dkk., Islamic Business and Economic Ethics, (Jakarta;Bumi Aksara, 2012)

Salvatore, Dominick, Teori Dan Soal-Soal Mikro Ekonomi, Edisi IV (Jakarta: Erlangga, 2007)

Saeed, Mohammad, Zafar U. Ahmed, Syeda-Masooda Mukhtar, "International Marketing Ethics an Islamic Perspective: A Value-Maximization Aprroach", Journal of Bisnis Ethics, 2001, Vol. 32, No.2, p. 127-142. 
Somad Rismi dan Priansa Donni Juni, Manajemen Komunikasi, (Bandung: Alfabeta. 2014)

Sunyoto, Danang, Prilaku Konsumen dan Pemasaran, (Yogyakarta, Center of Academic Publishing Service, 2015)

Tjiptono,.Fandy, Manajemen Jasa, (Yogyakarta : Andi, 2006)

Turnipseed, D.L., "Are good soldiers good? Exploring the Link Between Organisation Citizenship Behaviour and Personal Ethics," Journal of Business Research, 2002, Vol. 55, No. 1

Wray, B., Palmer, A. and Bejou, D., "Using Neural Network Analysis to Evaluate Buyer-Seller Relationships." European Journal of Marketing, 1994, Vol. 28, No. 10

Zubair, M. K. (2012). Aksioma Etika Dalam Ilmu Ekonomi Islam. EKBISI, 7(1), 88100. 